RESEARCH ARTICLE

\title{
Prevalence of Dental Amalgame in Uninassau School of Dentistry Clinic
}

\section{Ana Kaline da Silva Pereira* and Lívia Andrade Rodrigues}

University of Mauritius, Mauritius

*Corresponding author: Ana Kaline da Silva Pereira, University of Mauritius, Mauritius

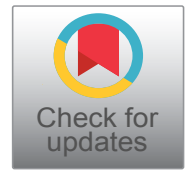

\section{Keywords \\ Prevalence of amalgam}

\section{Introduction}

The dental amalgam is any alloy consisting of mercury, in which we can also find silver (Ag), tin (Sn) and copper $(\mathrm{Cu})$ in its conventional filings. This type of restorative material is the focus of discussion in several countries, raising a great discussion about the continuity or elimination of its use, the reasons are: For the sake of offering little aesthetics or for providing possible risks for the dentist and the patient, due to the presence of mercury in its composition, since it is a volatile and toxic metal. Amalgam still in a certain way has a great importance in the present day, in a matter of value, for example (it is a material with a better cost/benefit, mainly in underdeveloped countries where the composite resin and the porcelain have very high values), provides excellent physical and mechanical properties such as high durability and tensile strength/dental attrition.

The objective of this study is to analyze the prevalence of amalgam use, based on the data obtained from the clinical records of the Uninassau School of Dentistry.

\section{Materials and Methods}

A retrospective analysis was made from the clinical records obtained at the dentistry clinical school of Uninassau, Recife, Brazil, in the year 2015, which were digitized by the students of the dentistry course of Uninassau of the $5^{\text {th }}$ period, with the guidance of Prof. Dr. Thiago Antônio de Souza Araújo.

In a sum of 1255 clinical records, we obtained an amount of 1017 patients who presented some type of restoration, having as exclusion criteria the individuals who did not present restored teeth and the clinical records with omitted data.

Through a detailed medical examination and an extrabuccal and intrabuccal physical exam performed by the graduates of Uninassau College, we analyzed the prevalence of dental amalgam, emphasizing the respective ages of each patient attended; being also observed, in more detail, the factor of the incidence of $\mathrm{AgHg}$ restorations with the type of dentition, be it anterior or posterior.

It is extremely relevant to note that no distinction was made regarding factors such as race, color, gender, social class or type of treatment performed; taking into account, only, the age range of each patient.

For a correct and precise analysis, absolute and relative distributions (percentage) were used in the two types of tables elaborated, one approaching the quantitative of people who presented amalgam or another type of restorative material; and another table showing the amount of AgHg-type restorations in each dentition.

This work was based on a proposal aimed at a descriptive statistical study with the tabulated and detailed results, showing the quantitative outcome of the prevalence of dental amalgam.

\section{Results}

According to the data reported, it is evident that the use of amalgam has been decreasing over the years, because in remote times the practice of using the amal-

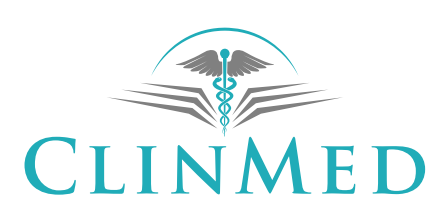

INTERNATIONAL LIBRARY

Citation: Pereira AKS, Rodrigues LA (2019) Prevalence of Dental Amalgame in Uninassau School of Dentistry Clinic. Int J Oral Dent Health 5:097. doi.org/10.23937/2469-5734/1510097

Accepted: August 30, 2019: Published: September 02, 2019

Copyright: (C) 2019 Pereira AKS, et al. This is an open-access article distributed under the terms of the Creative Commons Attribution License, which permits unrestricted use, distribution, and reproduction in any medium, provided the original author and source are credited. 
Table 1: Patients attended at the uninassau clinic.

\begin{tabular}{|l|l|l|l|l|}
\hline Age & \multicolumn{2}{|l|}{$\begin{array}{l}\text { Patients with } \\
\text { AgHg restoration }\end{array}$} & Total & \multicolumn{2}{|l|}{$\begin{array}{l}\text { AgHg restoration } \\
\text { Percentage }\end{array}$} \\
\cline { 2 - 5 } & yes & No & \multicolumn{2}{|l}{} \\
\hline $\mathbf{1 8 - 2 4}$ & 121 & 190 & 311 & $38.9 \%$ \\
\hline $\mathbf{2 5 - 3 4}$ & 89 & 142 & 231 & $38.52 \%$ \\
\hline $\mathbf{3 5 - 4 4}$ & 83 & 83 & 166 & $50 \%$ \\
\hline $\mathbf{4 5 - 6 0}$ & 76 & 88 & 164 & $46.34 \%$ \\
\hline $\mathbf{2 6 0}$ & 19 & 126 & 145 & $13.1 \%$ \\
\hline
\end{tabular}

Table 2: Detail of the percentage of $\mathrm{AgHg}$ restorations in each type of dentition.

\begin{tabular}{|l|l|l|}
\hline & $\begin{array}{l}\text { Number } \\
\text { of AgHg } \\
\text { restorations }\end{array}$ & Percentage \\
\hline Incisivo central $(11,21,31,41)$ & 9 & $0.5 \%$ \\
\hline Incisivo lateral $(12,22,32,42)$ & 13 & $0.67 \%$ \\
\hline Canino $(13,23,33,43)$ & 36 & $1.87 \%$ \\
\hline $1^{\circ}$ Pre-molar $(14,24,34,44)$ & 225 & $11.71 \%$ \\
\hline $2^{\circ}$ Pre-molar $(15,25,35,45)$ & 300 & $15.61 \%$ \\
\hline $1^{\circ}$ Molar $(16,26,36,46)$ & 590 & $30.71 \%$ \\
\hline $2^{\circ}$ Molar $(17,27,37,47)$ & 603 & $31.38 \%$ \\
\hline $3^{\circ}$ Molar $(18,27,38,48)$ & 145 & $7.54 \%$ \\
\hline
\end{tabular}

gam was greater due to the lack of a restorative material with characteristics similar to that of the same. If we take into account the total number of patients with amalgam restorations, we have the highest percentage in patients aged $35-44$ years, this value is $50 \%$, that is, half the people who were treated in this age group have some type of restoration of the AgHg type. And the group between 45 and 60 -years-old showed a percentage of $46 \%$ of the total number of patients attended, that is, it is clarified that amalgam is predominant in older patients. Making a caveat that individuals over 60 are more prone to extraction and use of dental prosthesis, so they presented a lower percentage of $13.1 \%$.

One of the notorious causes of the decrease in $\mathrm{AgHg}$ is that people are increasingly looking for procedures with a more favorable aesthetic, together with the fact that resins with amalgam-like characteristics (with respect to strength and durability) have been developed. This can be demonstrated through Table 1 with the following age groups: 18 to 24 years and 25 to 34 years, the figures are $39 \%$, a decrease of almost $11 \%$ in the prevalence of the use of this restorative material.

The teeth observed with a higher prevalence of AgHg-type restorations were the $1^{\text {st }}$ molars $(16,26,36$ and 46) and 2nd molars (17, 27, 37 and 47), for the reason that they are areas of great masticatory efforts, thus using restorative materials capable of withstanding the load exerted on the movements of dental occlusion. In comparison to the anterior teeth (central incisors, lateral incisors and canines) we noticed that there is a very significant difference when it comes to the use of amalgam, while in the second molar we have a $31.38 \%$ prevalence of amalgam use in the group of canines (dentition of the previous ones) was the one that presented a greater percentage, $1.87 \%$ of teeth that have restoration in amalgam. This is due to the reason that the anterior teeth do not have great relevance at the moment of chewing, thus not requiring a material that is highly resistant to compression, another factor would be in relation to aesthetic purposes, since the anterior teeth are the teeth that remain more visible [1-6] (Table 1 and Table 2).

\section{Conclusion}

The objective sought in this study was to show the prevalence of amalgam according to age groups. A selection was made with 1,017 patients in 2015 , and these were attended at the Clinical School of Dentistry of the Mauricio University of Nassau. The research performed demonstrated a high index of restorative amalgam material, predominantly in patients from 35 to 60 years. It was also found that molars are the ones that present the most use of $\mathrm{AgHg}$. It is considered, therefore, that amalgam was the most used material in dentistry in the 1990s, with the updating of dentistry and the search for esthetics these days, $\mathrm{AgHg}$ has a decrease in its use, because they do not present this requirement.

\section{References}

1. Nagem FH, Maria VS, Aragão HDN, Uchida MA, Carvalho JR, et al. (1997) Materiais restauradores: Aamálgama dental, Bauru.

2. Adair Luiz Stefanello Busato (1996) Dentística: Restauração em dentes posteriores, Artes médicas.

3. Luis Antonio Felippe, Luiz Clovis Cardoso Vieira, Andreas Lorenz Danker (1999) Amalgama dental: Fatos e controvérsias. Rev APCD 53: 41-45.

4. Garone N, Oliveira EC (1990) Atualização das principaisquestõesrelativasaoamálgama. Rev Paulista de Odontologia $12: 2-8$.

5. Clóvis Pagani, Ana Lúcia Marsílio, Alessandra Bühler Amendola, Cláudio Antonio Talge Carvalho, João Cândido de Carvalho (1999) Amálgama dental: Considerações gerais e atualidades. JBC 3: 25-28.

6. Silveira Rodrigo Richard da, Francisconi Paulo Afonso Silveira, Mondelli José (2000) Amálgama-mais de 160 anos de services prestados à odontologia. JBC 4: 85-88. 